\title{
Seasonal Effects of Backscattering Intensity of ALOS-2 PALSAR-2 (L-Band) on Retrieval Forest Biomass in the Tropics
}

\author{
Luong Viet Nguyen ${ }^{1 *}$, Hieu Van Nguyen', Lap Quoc Kieu², Tu Trong To', Thanh Kim Thi Phan', \\ Tuan Anh Pham1, Chi Kim Tran1
}

${ }^{1}$ Space Technology Institute, Vietnam Academy of Science and Technology, Hanoi, Vietnam

${ }^{2}$ Thai Nguyen University of Sciences, Thai Nguyen City, Vietnam

Email: *nvluong@sti.vast.vn

How to cite this paper: Nguyen, L. V., Van Nguyen, H., Kieu, L. Q., To, T. T., Phan, T. K. T., Pham, T. A., \& Tran, C. K. (2020). Seasonal Effects of Backscattering Intensity of ALOS-2 PALSAR-2 (L-Band) on Retrieval Forest Biomass in the Tropics. Journal of Geoscience and Environment Protection, 8, 26-40.

https://doi.org/10.4236/gep.2020.811002

Received: September 4, 2020

Accepted: November 6, 2020

Published: November 9, 2020

Copyright ( 2020 by author(s) and Scientific Research Publishing Inc. This work is licensed under the Creative Commons Attribution International License (CC BY 4.0).

http://creativecommons.org/licenses/by/4.0/

\begin{abstract}
This research has used the L-band radar from ALOS-2 PALSAR-2 and field work data for evaluation of seasonal effects of backscattering intensity on retrieval forest biomass in the tropics. The effects of seasonality and $\mathrm{HH}$, and HV polarizations of the SAR data on the biomass were analyzed. The dry season HV polarization could explain $61 \%$ of the biomass in this study region. The dry season HV backscattering intensity was highly sensitive to the biomass compared to the rainy season backscattering intensity. The SAR data acquired in the rainy season with humid and wet canopies were not very sensitive to the in situ biomass. Strong dependence of the biomass estimates with season of SAR data acquisition confirmed that the choice of right season SAR data is very important for improving the satellite based estimates of the biomass. This research expects that the results obtained in this research will contribute to monitoring of the quantity and quality of forest biomass in Vietnam and other tropical countries.
\end{abstract}

\section{Keywords}

L-Band SAR, ALOS-2 PALSAR-2, Backscattering Intensity, Tropical Forest Biomass, Vietnam

\section{Introduction}

The role of forests to mitigate climate change has been strongly recognized again in the Paris Agreement in 2015 like as "key components of landmark climate deal agreed as well as an instrument to contribute to reducing emissions and 
enhancing carbon sinks" on Paris Agreement (COP 21, 2015). The information of forest biomass is essential for increasing understanding of the terrestrial carbon cycle and judicial management of forest resources. Forests sequestrate atmospheric carbon dioxide in the form of biomass during photosynthesis (IPCC, 2003; FAO, 2009; Way \& Pearcy, 2012). Therefore, forest biomass has an important role in the global carbon cycle (Brown, 1997; IPCC 2006; Gibbs et al., 2007). When forests are destroyed, more carbon is added to the atmosphere which accelerates climate change. Accurate monitoring of forest biomass and $\mathrm{CO}_{2}$ sequestration rates are immensely important for increasing understanding of global carbon cycles, improving climate change forecasting models, and climate change mitigation and adaptation strategies (FAO, 1997; GCOS, 2006; Gibbs et al., 2007; FAO, 2009, 2010; Stone \& León, 2011). Global monitoring of forest carbon is also urgently needed for the United Nation program on Reducing Emissions from Deforestation and Degradation (REDD+), a financial payment mechanism for environmental services (Stone \& León, 2011; UN-REDD Vietnam, 2012). However, estimating biomass from satellite data is challenging due to the diverse nature of forests, especially tropical forests (Lefsky et al., 2002; Lu, 2006; Gibbs et al., 2007; FAO, 2010; Sinha et al., 2015).

Satellite remote sensing technology has many advantages for biomass estimates over traditional field survey based methods, particularly at larger scales. Therefore, it has been used by many researchers for biomass estimates (Lu, 2006; Gibbs et al., 2007; Ghasemi et al., 2011). Satellite based estimation of biomass relies on optical, radar, and more recently lidar techniques. Limitations of optical data based biomass estimates have been reported by researchers including saturation over large biomass regions, very low correlation, and difficulties in detecting vertical structure (Ripple et al., 1991; Vincent \& Saatchi, 1999; GCOS, 2006; Gibbs et al., 2007; Gonzalez et al., 2010; Brewer et al., 2011; Sinha et al., 2015; Pham et al., 2019).

Lidar sensors have performed excellent estimates even in forests with high biomass and woody volumes by directly measuring the structure of the forest, i.e., canopy height and vertical distribution (Vincent \& Saatchi, 1999; Lefsky et al., 2002; Zhao et al., 2009; Bortolot \& Wynne, 2005; Moskal \& Zheng, 2011; Kankare et al., 2013; Sheridan et al., 2014; Hansen et al., 2013). However, large scale application of lidar data is not economically feasible at present ( $\mathrm{Lu}, 2006$; Gibbs et al., 2007; Brewer et al., 2011).

Radar remote sensing from satellites has high potential for biomass estimates at large scale because of its penetrability through clouds, applicability with night time, coverage at large scale, availability of seasonal data, and lower saturation in dense forests (Ulaby et al., 1981; Wu, 1987; Jensen, 2005; Kellndorfer et al., 2004; Ramankutty et al., 2007; Gibbs et al., 2007; Le Toan et al., 2011; Brolly \& Woodhouse, 2012; Sinha et al., 2015; Luong et al., 2016; Luong et al., 2019). The long-wavelength SAR satellite is expected to have much promise for estimates of forest biomass (Ramankutty et al., 2007; FAO, 2009; Le Toan et al., 2011; Pham 
et al., 2020).

The backscattering intensity of L-band and P-band SAR data have demonstrated sensitivity to structure, cover, volume, and biomass of the forests penetrating into the branches and stems of trees (Jensen, 2005; Sun et al., 2002; Balzter, 2001; Balzter et al., 2007; Luong et al., 2016). A number of previous studies have shown an impressive relationship between the SAR data and biomass ( $\mathrm{Wu}$, 1987; Le Toan et al., 1992; Dobson et al., 1992; Ranson \& Sun, 1994; Luckman et al., 1997; Santos et al., 2002; Mitchard et al., 2011; Sandberg et al., 2011; Peregon \& Yamagata, 2013). On the other hand, several researchers have reported saturation problems with the L-band SAR backscattering over high biomass regions. The major techniques for SAR based estimates of biomass attempted by a number of researchers so far are regression modelling (Le Toan et al., 1992; Morel et al., 2011; Englhart et al., 2011; Carreiras et al., 2013), dual-wavelength SAR interferometry (Balzter et al., 2007); image texture analysis (Champion et al., 2008); random volume over ground model (Hajnsek et al., 2009), water cloud model (Cartus et al., 2012), combination of forest structure and radiative transfer models (Brolly \& Woodhouse, 2014), electromagnetic modelling (Mermoz et al., 2015), multivariate relevance vector regression (Sharifi et al., 2016). SAR data have been used for estimating biomass at different scales from local to regional/country level: pine plantation in Southwest Alabama (Wu, 1987), Mount Sharsta region of Northern California (Richards et al., 1987), plantation forest of the Landes forest in southwestern France (Le Toan et al., 1992), Brazilian Amazon (Luckman et al., 1997; Santos et al., 2002), Nuuksio Natural Park in Southern Finland (Mika et al., 2008), the Queensland in Australia (Lucas et al., 2010), Mozambique in Zambézia province (Carreiras et al., 2013), Cambodia (Avtar et al., 2013), and Cameroon (Mermoz et al., 2015).

Several studies have shown that: backscattering intensity is also affected by a number of site conditions such as environmental temperatures (Ranson \& Sun, 1994), moistures (Bindlish \& Barros, 2001; Kasischke et al., 2009; Koyama, 2011; Huang et al., 2015).

In this research used the Advanced Land Observing Satellite-2 (JAXA, 2014), a Japanese satellite launched in 2014, which operates in L-band radar and collects very high spatial resolution. Currently, satellite image data from ALOS-2 is available and meets the global supply capability to many different applications.

The objective of this study was to assess the effects of seasons in the tropics on the quality of the ALOS-2 PALSAR-2 (L-band) satellite imagery.

\section{Study Area and Data}

\subsection{Study Area}

This research was carried out in Yok Don National Park (YDNP) is located in Dak Lac and Dak Nong provinces, Central Highlands of Vietnam. This park was chosen for this study because of several reasons: 1) It is located in the tropical 
forest with characteristics of the typical structure in Vietnam;2) This park is the largest national park in Vietnam; 3) It is located on relatively flat ground, average slope from $7^{\circ}-10^{\circ}$, thereby minimizing the effect of topography on this study; 4) The road network around and inside the study area is not too difficult to transport, and perform fieldwork.

The Yok Don National Park is located between latitude $12^{\circ} 45^{\prime}-13^{\circ} 10^{\prime \prime}$ and longitude $107^{\circ} 29^{\prime} 30^{\prime \prime}-107^{\circ} 48^{\prime} 30^{\prime \prime}$ (Figure 1).

Topography: The whole area is divided into two main geographical terrain forms: fairly smooth pen plain, and being lower towards the Mekong River. The other terrain form, low hills, and mountains is lying along the north riverbank. The topography of this park contains relatively plain topography and is located at an altitude of $200-300 \mathrm{~m}$ above sea level. Most of the terrain with an average slope from $7^{\circ}-10^{\circ}$ (Nguyen, 2009).

Climate: This region is a tropical monsoon that has well-defined and distinct dry and rainy seasons. The rainy season runs from May to November. The average rainfall obviously changes among months of the rainy season and the dry season. It is very low in the dry season from October to April; the average value is less than $50 \mathrm{~mm}$. In contrast, it is very high from April to August and then quickly decreases in September and October at the end of the rainy season. The average annual rainfall about $1530 \mathrm{~mm}$, while the average annual evaporation is $1470 \mathrm{~mm}$, and the mean monthly temperature is around $25^{\circ} \mathrm{C}$ (Nguyen, 2009).

Compared to rainfall and humidity, the monthly change of air temperature is very high. April and May are months whose average air temperature is highest, about $27^{\circ} \mathrm{C}$, while the average temperature in December and January is lowest, about $14^{\circ} \mathrm{C}$.

Biodiversity: This park is very rich in biodiversity: 854 species, belonging to 478 vascular plant species and 129 families of 4 phyla have been recorded (Canh et al., 2009; Nguyen, 2015). This park has two major types of forest: deciduous broadleaf forest and evergreen broadleaf forest. The dominant tree species in the deciduous broadleaf forest are Dipterocarpus tuberculatus, Dipterocarpus obtusifolius, Terminalia tomentosa, and Shorea obtuse. The evergreen broadleaf forest mainly comprises of Michelia mediocris, Cinamomum iners, Syzygium zeylanicum, Syzygium wightianum, Garruga pierrei, Gonocaryum lobbianum, Schima superba, Camellia assamica, and Lithocarpus fenestratus. This park has 21 tree species in the list of the Red Data Book of Vietnam (Nguyen, 2015). A total of 89 species of mammals, 250 species of birds, 48 species of reptiles, 16 species of amphibians, 31 species of fish, and 437 species of butterflies were recorded (Canh et al., 2009; Nguyen, 2015). This park is one of the most important protected areas and provides a suitable habitat for conservation of globally endangered species in Southeast Asia such as wild elephants, wild cow, deer and a lot of birds such as peacocks and several species of birds of prey and large water birds (Nguyen, 2015). 


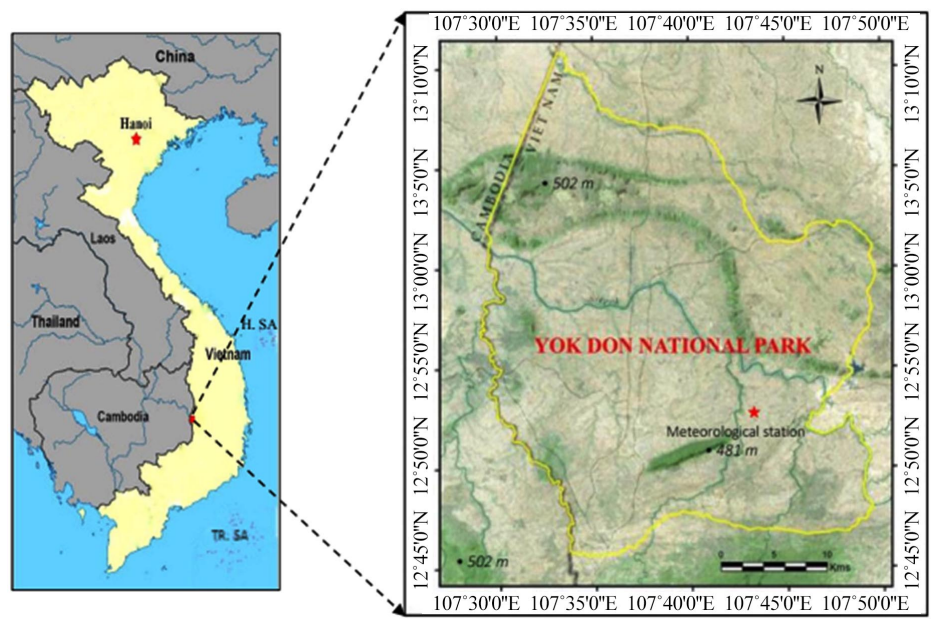

Figure 1. Location of the study area Yok Don National Park in Vietnam (boundary is the yellow polygon).

\subsection{ALOS-2 PALSAR-2 Data}

In this study, we used the Advanced Land Observing Satellite-2 Synthetic Aperture Radar (ALOS-2 SAR), provided by Japan Aerospace Exploration Agency (JAXA), a Japanese satellite launched in 2014, which operates in L-band radar and collects very high spatial resolution data. ALOS-2 SAR data with level 2.1, which has $6.25 \mathrm{~m}$ pixel resolution was selected from October 2014 (rainy season) to February 2015 (dry season). The digital number (DN) values of the SAR images in both the $\mathrm{HH}$ and $\mathrm{HV}$ polarizations were calibrated by calculating the backscattering intensity using Equation (1) (JAXA, 2014).

$$
\sigma^{\circ}=10 \times \log _{10}\left(\mathrm{DN}^{2}\right)+\mathrm{CF}
$$

In Equation (1), the $\sigma^{\circ}$ is the sigma-naught backscattering intensity in the units of decibels $(\mathrm{dB})$, and $\mathrm{CF}$ is the calibration factor which is currently set as -83 (JAXA, 2014).

The details on the ALOS-2 SAR images used in this research are described in Table 1. Both dry and rainy season SAR images were used, acquired with the same off-nadir angle $\left(32.9^{\circ}\right)$ in descending modes in order to avoid bias related to observation angles.

\section{Methodology}

\subsection{Field Work}

The in situ measurements were conducted by establishing the sample plots according to the inventory guideline available for the Central Highlands region (Van Vo et al., 2006; Vu Tan et al., 2012). All sample plots were established by meeting the criteria of representativeness of different forest types across the study areas such as 1) Evenly distributed in the study area; 2) Representativeness of the forest types in the study area; 3) Representativeness for topographic conditions; 4) At least 100-m apart from trains, roads, streams, and rivers. We carefully designed the sample plots in such a way that they were at least 100 -m apart 
Table 1. The ALOS-2 PALSAR-2 data used in this research.

\begin{tabular}{cccccc}
\hline No. & Obs. date & Scene ID & Polar. & Obs. angle Seasons \\
\hline 1 & 5 Oct. 2014 & ALOS2019900240-141005-FBDR2.1GUA & HH, HV & $32.9^{\circ}$ & Rainy \\
2 & 5 Oct. 2014 & ALOS2019900250-141005-FBDR2.1GUA & HH, HV & $32.9^{\circ}$ & Rainy \\
3 & 22 Feb. 2015 & ALOS2040600240-150222-FBDR2.1GUA & HH, HV & $32.9^{\circ}$ & Dry \\
4 & 22 Feb. 2015 & ALOS2040600250-150222-FBDR2.1GUA & HH, HV & $32.9^{\circ}$ & Dry \\
\hline
\end{tabular}

from trails, roads, streams, and rivers to avoid the signals from unwanted surface types for sensitivity analysis.

Each sample plot established during the forest inventory was $(50 \mathrm{~m} \times 50 \mathrm{~m})$ with an area of 0.25 ha. Measurement of the diameter at breast height (D) and total tree height $(\mathrm{H})$ of all the trees larger than $5 \mathrm{~cm}$ diameter at breast height located inside the sample plots. The tree diameter and height were measured by using laser diameter (Criterion RD1000 Laser) and laser height (Trupulse 360B Laser) instruments. The central geo-location (latitude and longitude) of each sample plot was recorded by using GPS instruments.

The RGB color composite image was created by using the $\mathrm{HH}$ channel for red (R), HV channel for green (G), and the ratio HH/HV for blue (B). The distribution of sample plots used in this research is shown in Figure 2 and Figure 3 using RGB color composite of the SAR color composite images. Distinct variation between the rainy season and dry season RGB images in Yok Don National Park were observed as shown in Figure 2 and Figure 3.

\subsection{Estimation of Forest Biomass}

This research converted the individual tree biometry data: diameter at breast height $(\mathrm{D})$ and total tree height $(\mathrm{H})$ measured during the forest inventory into above ground biomass (AGB) using the allometric equations. The research used separate allometric equations for calculating the AGB of the deciduous and evergreen forests (Vu Tan et al., 2012). The allometric equations used for calculating the AGB of deciduous and evergreen forest types are given in Equation (2) and Equation (3) respectively.

$$
\begin{gathered}
\mathrm{AGB}=0.14 \times \mathrm{D}^{2.31} \\
\mathrm{AGB}=0.098 * \exp (2.08 * \operatorname{Ln}(\mathrm{D})+0.71 * \operatorname{Ln}(\mathrm{H})+1.12 * \operatorname{Ln}(\mathrm{WD}))
\end{gathered}
$$

In Equation (2) and Equation (3), where: AGB is the above ground biomass of a tree in kilograms $(\mathrm{kg}) ; \mathrm{D}$ is the diameter at breast height measured at $1.3-\mathrm{m}$ above the ground level; $\mathrm{H}$ is the total height of tree in meters $(\mathrm{m})$; WD is the wood density of tree in tones dry matter per fresh cubic meters $\left(\mathrm{Mg} \cdot \mathrm{m}^{-3}\right)$.

\section{Results and Discussions}

\subsection{Field Survey Results}

The plot wise distribution of forest structural variation shows that: In total, 110 sample plots were established in the study area. Of which, 10 sample plots were from the evergreen forest and 100 sample plots were from the dipterocarp forest, 
the sample plots represent larger variation of the diameter at breast height (8.14 - $48.74 \mathrm{~cm})$, tree height $(6.13-18.23 \mathrm{~m})$, tree density $\left(220-2800\right.$ trees $\left.^{-h^{-1}}\right)$ and

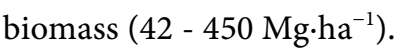

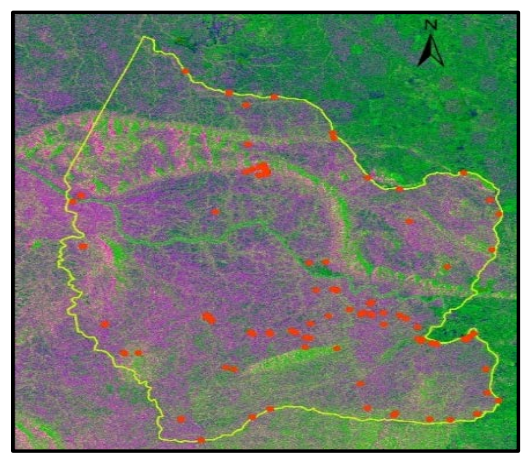

(a)

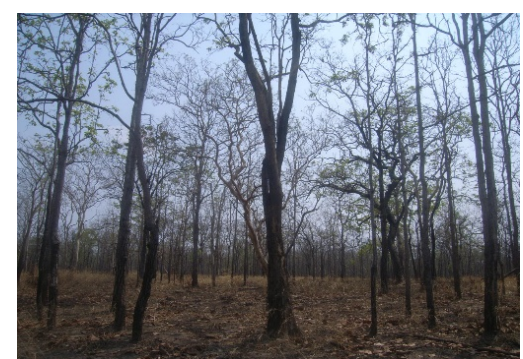

(b)

Figure 2. Distribution of sample plots. (a) Dry season RGB color composite images; (b) Forest in rainy season.

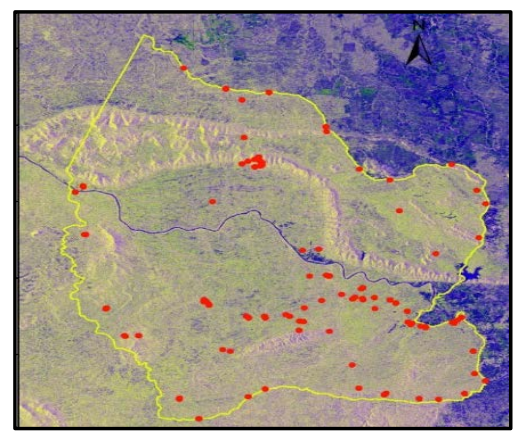

(a)

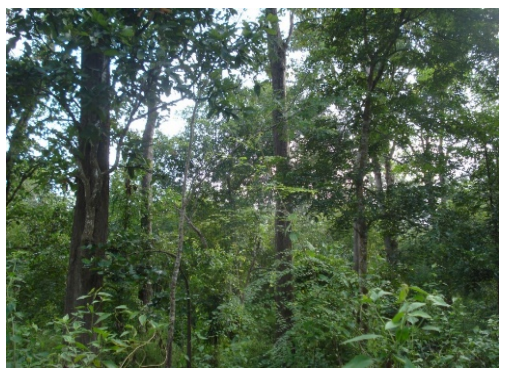

(b)

Figure 3. Distribution of sample plots. (a) Rainy season RGB color composite images; (b) Forest in rainy season. 


\subsection{The Polarizing Difference of L-Band SAR to the Retrieval Forest Biomass}

The sensitivity of biomass with the backscattering intensity of the HH and HV polarizations for the dry season was analyzed using the coefficient of determination $\left(\mathrm{R}^{2}\right)$ and Root Mean Square Error (RMSE). As shown in Figure 4(a) and Figure 4(b), the HV polarization was highly related to both the biomass $\left(\mathrm{R}^{2}=\right.$ $\left.0.61, \mathrm{RMSE}=38.28 \mathrm{Mg} \cdot \mathrm{ha}^{-1}\right)$; whereas the HH polarization did not show a significant relationship with the above ground biomass $\left(\mathrm{R}^{2}=0.33, \mathrm{RMSE}=65.87\right.$ $\left.\mathrm{Mg} \cdot \mathrm{ha}^{-1}\right)$.

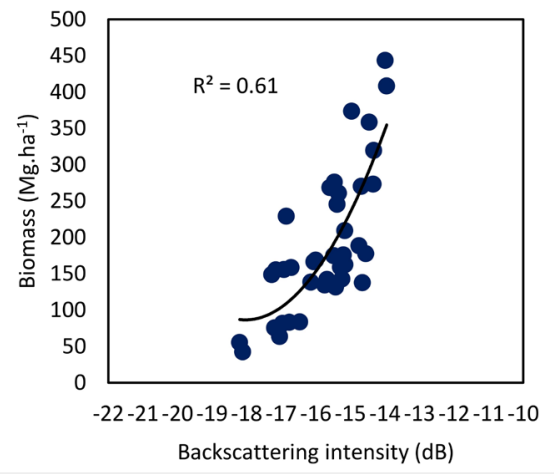

(a)

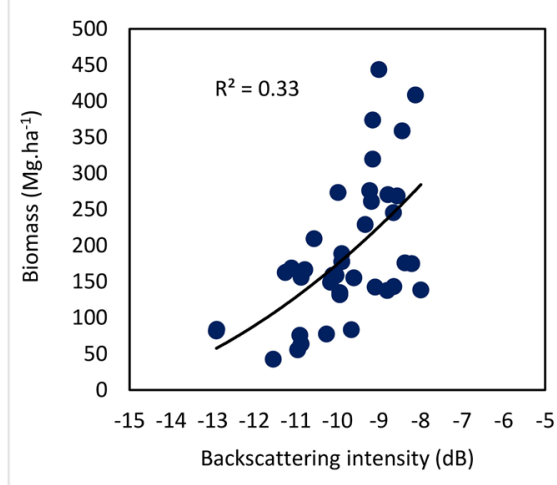

(b)

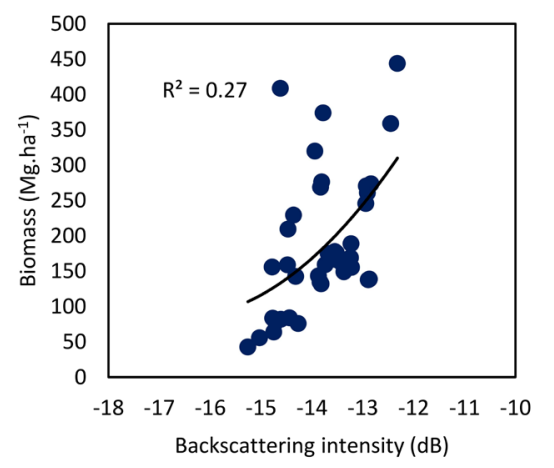

(c) 


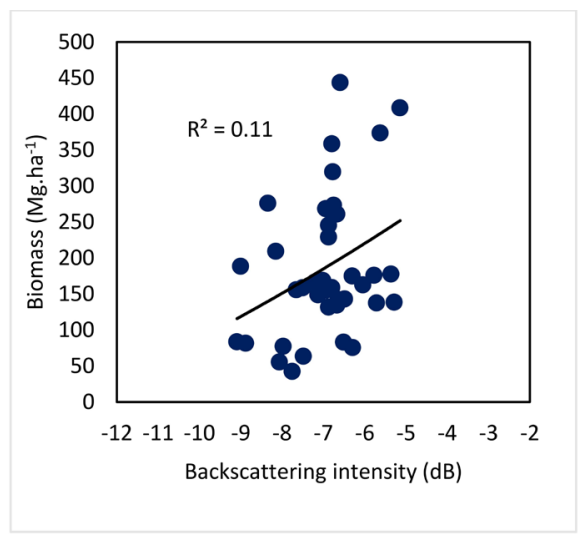

(d)

Figure 4. The relationship between the biomass, and backscattering intensity. (a) HV in dry season; (b) HH in dry season; (c) HV in rainy season; and (d) HH rainy season.

The high sensitivity of the HV polarization towards biomass was found for both the dry and rainy season SAR data. This result highlights the importance of HV polarization for the estimates of biomass.

The saturation of the radar signal was clearly observed at high biomass level (250 - $300 \mathrm{Mg} \cdot \mathrm{ha}^{-1}$ biomass). None of the biomass data correlated with the rainy season HV polarization data as highly as the dry season HV polarization data.

\subsection{The Seasonal Difference of L-Band SAR to the Retrieval Forest Biomass}

The sensitivity of the ALOS-2 PALSAR-2 data (HV and HH polarizations) acquired during dry season and rainy season on biomass was analyzed. The relationship between biomass and dry season SAR data is shown in Figure 4(a) and Figure 4(b); and the relationship between biomass and rainy season SAR data is shown in Figure 4(c) and Figure 4(d). The dry season backscattering intensity of the $\mathrm{HH}$ and HV polarizations was highly sensitive to the biomass than the rainy season backscattering intensity. The higher relationship between the dry season HV polarization and biomass $\left(\mathrm{R}^{2}=0.61, \mathrm{RMSE}=38.28 \mathrm{Mg} \cdot \mathrm{ha}^{-1}\right)$ was obtained. However, the relationship between the rainy season HV polarization and biomass was relatively lower $\left(\mathrm{R}^{2}=0.27, \mathrm{RMSE}=71.60 \mathrm{Mg} \cdot \mathrm{ha}^{-1}\right)$ than the dry season. The relationship between rainy season $\mathrm{HV}$ polarization. This analysis suggests that dry season SAR data is more important for estimating the biomass than the rainy season data. The effect of seasonality for the SAR data was clearly observed in this research.

\subsection{Validation Result}

In this research used 38 sample plots data were used to test the validity of the fitted linear regression models for the prediction of biomass. In Figure 5 shown, our model could explain $59 \%$ variation of the biomass $\left(R^{2}=0.59\right.$, RMSE $=40.28$ $\left.\mathrm{Mg} \cdot \mathrm{ha}^{-1}\right)$. 


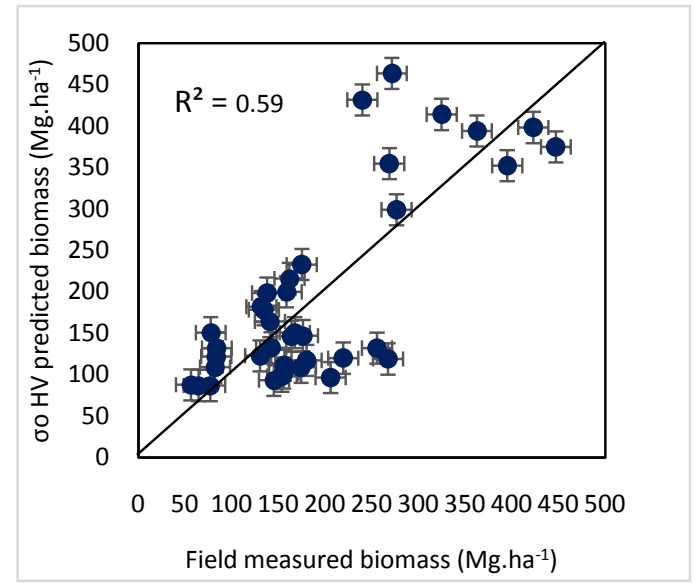

Figure 5. Validation of the SAR data based predicted results of above ground biomass. The 1:1 plot between the predicted and field data are shown.

\section{Conclusion}

In this research, the sensitivity of the biomass to the polarizations of ALOS-2 PALSAR-2 data (SAR data), and the season of acquisition of SAR data were analyzed. The relationship between the ALOS-2 PALSAR-2 based HV polarization backscattering intensity and field measured biomass since 59\% variation in forest biomass could be explained by the HV polarization data.

This study found out that dry season SAR data is more important for estimating the biomass than the rainy season data. The effect of seasonality for the SAR data was clearly observed in this research. This result confirmed that: the importance of SAR data mainly from the dry season.

Therefore, the choice of season in which SAR data is acquired is very important for satellite based estimates of the biomass.

We expect that the results obtained in this research would be useful for promoting emission reduction programs in the forestry sector, and to achieve sustainable forest management goals in Vietnam and other tropical countries.

\section{Acknowledgements}

The authors are grateful to the VT-CN. 03/17-20 project under National Research on Space Science and Technology Program of Vietnam (2016-2020) for financial support to carry out this research. We would like to thank JAXA for providing ALOS-2 PALSAR-2 data for this study in the framework of ALOS Research program, PI No. 1172.

\section{Conflicts of Interest}

The authors declare no conflicts of interest regarding the publication of this paper.

\section{References}

Avtar, R., Suzuki, R., Takeuchi, W., \& Sawada, H. (2013). PALSAR 50 m Mosaic Data 
Based National Level Biomass Estimation in Cambodia for Implementation of REDD+ Mechanism. PLoS ONE, 8, e74807. https://doi.org/10.1371/journal.pone.0074807

Balzter, H. (2001). Forest Mapping and Monitoring with Interferometric Synthetic Aperture Radar (InSAR). Progress in Physical Geography, 25, 159-177. https://doi.org/10.1177/030913330102500201

Balzter, H., Rowland, C. S., \& Saich, P. (2007). Forest Canopy Height and Carbon Estimation at Monks Wood National Nature Reserve, UK, Using Dual-Wavelength SAR Interferometry. Remote Sensing of Environment, 108, 224-239.

https://doi.org/10.1016/j.rse.2006.11.014

Bindlish, R., \& Barros, A. P. (2001). Parameterization of Vegetation Backscatter In Radar-Based, Soil Moisture Estimation. Remote Sensing of Environment, 76, 130-137. https://doi.org/10.1016/S0034-4257(00)00200-5

Bortolot, Z. J., \& Wynne, R. H. (2005). Estimating Forest Biomass Using Small Footprint LiDAR Data: An Individual Tree-Based Approach That Incorporates Training Data. ISPRS Journal of Photogrammetry and Remote Sensing, 59, 342-360. https://doi.org/10.1016/j.isprsjprs.2005.07.001

Brewer, K. C., Monty, J., Johnson, A., Evans, D., \& Fisk, H. (2011). Forest Carbon Monitoring: A Review of Selected Remote Sensing and Carbon Measurement Tools for REDD+ (35 p). RSAC-10018-RPT1, Salt Lake City, UT: U.S. Department of Agriculture, Forest Service, Remote Sensing Applications Center.

Brolly, M., \& Woodhouse, I. H. (2012). A “Matchstick Model” of Microwave Backscatter from a Forest. Ecological Modelling, 237, 74-87. https://doi.org/10.1016/j.ecolmodel.2012.04.014

Brolly, M., \& Woodhouse, I. H. (2014). Long Wavelength SAR Backscatter Modelling Trends as a Consequence of the Emergent Properties of Tree Populations. Remote Sensing, 6, 7081-7109. https://doi.org/10.3390/rs6087081

Brown, S. (1997). Estimating Biomass and Biomass Change of Tropical Forests: A Primer (Vol. 134). Food and Agriculture Organization.

Canh, N. X. et al. (2009). Report on Conservation Planning and Sustainable Development of Yok Don National Park in 2010-2020 (140 p). Ministry of Agriculture and Rural Development (MARD).

Carreiras, J. M. B., Melo, J. B., \& Vasconcelos, M. J. (2013). Estimating the Above-Ground Biomass in Miombo Savanna Woodlands (Mozambique, East Africa) Using L-Band Synthetic Aperture Radar Data. Remote Sensing, 5, 1524-1548. https://doi.org/10.3390/rs5041524

Cartus, O., Santoro, M., \& Kellndorfer, J. (2012). Mapping Forest Aboveground Biomass in the Northeastern United States with ALOS PALSAR Dual-Polarization L-Band. Remote Sensing of Environment, 124, 466-478. https://doi.org/10.1016/j.rse.2012.05.029

Champion, I. et al. (2008). Radar SAR Images Texture as a Function of Forest Stand Age. International Journal of Remote Sensing, 29, 1795-1800.

https://doi.org/10.1080/01431160701730128

COP 21 (2015).

https://unfccc.int/process-and-meetings/the-paris-agreement/the-paris-agreement

Dobson, M. C., Ulaby, F. T., Le Toan, T., Beaudoin, A., Kasischke, E. S., \& Christensen, N. (1992). Dependence of Radar Backscatter on Coniferous Forest Biomass. IEEE Transactions on Geoscience and Remote Sensing, 30, 412-415.

https://doi.org/10.1109/36.134090

Englhart, S., Keuck, V., \& Siegert, F. (2011). Aboveground Biomass Retrieval in Tropical 
Forests-The Potential of Combined X- and L-Band SAR Data Use. Remote Sensing of Environment, 115, 1260-1271. https://doi.org/10.1016/j.rse.2011.01.008

FAO (1997). Estimating Biomass and Biomass Change of Tropical Forests: A Primer. FAO Forestry Paper-134. http://www.fao.org/docrep/w4095e/w4095e00.HTM

FAO (2009). Global Terrestrial Observing System Rome. Assessment of the Status of the Development of the Standards for the Terrestrial Essential Climate Variables, Rome, 2009. Biomass. Version 10, 25 May 2009.

FAO (2010). Global Forest Resources Assessment 2010-Main Report (378 p). FAO Forestry Paper 163, Rome.

GCOS (2006). Systematic Observation Requirements for Satellite-Based Products for Climate. Supplemental Details to the Satellite-Based Component of the Implementation Plan for the Global Observing System for Climate in Support of the UNFCCC (No. 1338). GCOS-107/WMO-TD.

Ghasemi, N., Sahebi, M. R., \& Mohammadzadeh, A. (2011). A Review on Biomass Estimation Methods Using Synthetic Aperture Radar Data. International Journal of Geomatics and Geosciences, 1, 776-788.

Gibbs, H. K., Brown, S., Niles, J. O., \& Foley, J. A. (2007). Monitoring and Estimating Tropical Forest Carbon Stocks: Making REDD a Reality. Environmental Research Letters, 2, Article ID: 045023. https://doi.org/10.1088/1748-9326/2/4/045023

Gonzalez, P., Asner, G. P., Battles, J. J., Lefsky, M. A., Waring, K. M., \& Palace, M. (2010). Forest Carbon Densities and Uncertainties from Lidar, QuickBird, and Field Measurements in California. Remote Sensing of Environment, 114, 1561-1575.

https://doi.org/10.1016/j.rse.2010.02.011

Hajnsek, I., Kugler, F., Lee, S. K., Papathanassiou, K. P. (2009). Tropical-Forest-Parameter Estimation by Means of Pol-InSAR: The INDREX-II Campaign. IEEE Transactions on Geoscience and Remote Sensing, 47, 481-493. https://doi.org/10.1109/TGRS.2008.2009437

Hansen, J., Kharecha, P., Sato, M., Masson-Delmotte, V., Ackerman, F., Beerling, D. J., \& Rockstrom, J. (2013). Assessing "Dangerous Climate Change": Required Reduction of Carbon Emissions to Protect Young People, Future Generations and Nature. PloS ONE, 8, e81648. https://doi.org/10.1371/journal.pone.0081648

Huang, W., Sun, G., Zhang, Z., \& Ni, W. (2015). Sensitivity of Multi-Source SAR Backscatter to Changes of Forest Aboveground Biomass. Remote Sensing, 7, 9587-9609. https://doi.org/10.3390/rs70809587

IPCC (2003). Good Practice Guidance for Land Use, Land-Use Change and Forestry. IPCC National Greenhouse Gas Inventories Programme Technical Support Unit, Printed in Japan.

IPCC (2006). Chapter 4. Forest Land. In Guidelines for National Greenhouse Gas Inventories. Volume 4: Agriculture, Forestry and Other Land Use (83 p). IPCC.

JAXA (2014). ALOS-2/Calibration Result of JAXA Standard Products. Japan Aerospace Exploration Agency, Earth Observation Research Center. https://www.eorc.jaxa.jp/ALOS-2/en/calval/calval_index.htm

Jensen, J. R. (2005). Remote Sensing of the Environment: An Earth Resource Perspective (557 p). Pearson Education India. Third Indian Reprint.

Kankare, V., Vastaranta, M., Holopainen, M., Räty, M., Yu, X., Hyyppä, J., \& Viitala, R. (2013). Retrieval of Forest Aboveground Biomass and Stem Volume with Airborne Scanning LiDAR. Remote Sensing, 5, 2257-2274. https://doi.org/10.3390/rs5052257

Kasischke, E. S., Bourgeau-Chavez, L. L., Rober, A. R., Wyatt, K. H., Waddington, J. M., \& Turetsky, M. R. (2009). Effects of Soil Moisture and Water Depth on ERS SAR Back 
Scatter Measurements from an Alaskan Wetland Complex. Remote Sensing of Environment, 113, 1868-1873. https://doi.org/10.1016/j.rse.2009.04.006

Kellndorfer, J., Walker, W., Pierce, L., Dobson, C., Fites, J. A., Hunsaker, C., \& Clutter, M. (2004). Vegetation Height Estimation from Shuttle Radar Topography Mission and National Elevation Datasets. Remote Sensing of Environment, 93, 339-358. https://doi.org/10.1016/j.rse.2004.07.017

Koyama, C. N. (2011). Quantitative Estimation of Surface Soil Moisture in Agricultural Landscapes Using Spaceborne Synthetic Aperture Radar Imaging at Different Frequencies and Polarizations. Doctoral Dissertation, Universität zu Köln.

Le Toan, T., Beaudoin, A., Riom, J., \& Guyon, D. (1992). Relating Forest Biomass to SAR Data. IEEE Transactions on Geoscience and Remote Sensing, 30, 403-411. https://doi.org/10.1109/36.134089

Le Toan, T., Quegan, S., Davidson, M. W. J., Balzter, H., Paillou, P., Papathanassiou, K., Plummer, S., Rocca, F., Shugart H., \& Ulander, L. (2011). The BIOMASS Mission: Mapping Global Forest Biomass to Better Understand the Terrestrial Carbon Cycle. Remote Sensing of Environment, 115, 2850-2860.

https://doi.org/10.1016/j.rse.2011.03.020

Lefsky, A. M., Warren, B. C., Geoffrey, G. P., \& Harding, J. D. (2002). Lidar Remote Sensing for Ecosystem Studies: Lidar, an Emerging Remote Sensing Technology That Directly Measures the Three-Dimensional Distribution of Plant Canopies, Can Accurately Estimate Vegetation Structural Attributes and Should Be of Particular Interest to Forest, Landscape, and Global Ecologists. BioScience, 52, 19-30. https://doi.org/10.1641/0006-3568(2002)052[0019:LRSFES]2.0.CO;2

Lu, D. S. (2006). The Potential and Challenge of Remote Sensing-Based Biomass Estimation. International Journal of Remote Sensing, 27, 1297-1328. https://doi.org/10.1080/01431160500486732

Lucas, R., Armston, J., Fairfax, R., Fensham, R., Accad, A., Carreiras, J. et al. (2010). An Evaluation of the ALOS PALSAR L-Band Backscatter-Above Ground Biomass Relationship Queensland, Australia: Impacts of Surface Moisture Condition and Vegetation Structure. Selected Topics in Applied Earth Observations and Remote Sensing. IEEE Journal, 3, 576-593. https://doi.org/10.1109/JSTARS.2010.2086436

Luckman, A., Baker, J., Kuplich, M. T., Yanasse, F. C. C., \& Frery, C. A. (1997). A Study of the Relationship between Radar Backscatter and Regenerating Tropical Forest Biomass for Spaceborne SAR Instruments. Remote Sensing of Environment, 60, 1-13. https://doi.org/10.1016/S0034-4257(96)00121-6

Luong, N. V., Tateishi, R., Thanh Nguyen, H. C., Sharma, R., Trong To, T., \& Mai Le, S. (2016). Estimation of Tropical Forest Structural Characteristics Using ALOS-2 SAR Data. Advanced Remote Sensing, 5, 131-144. https://doi.org/10.4236/ars.2016.52011

Luong, V. N. et al. (2019). Biomass Estimation and Mapping of Can GIO Mangrove Biosphere Reserve in South of Viet Nam Using ALOS-2 PALSAR-2 Data. Applied Ecology and Environmental Research, 17, 15-31. https://doi.org/10.15666/aeer/1701_015031

Mermoz, S., Réjou-Méchain, M., Villard, L., Le Toan, T., Rossi, V., \& Gourlet-Fleury, S. (2015). Decrease of L-Band SAR Backscatter with Biomass of Dense Forests. Remote Sensing of Environment, 159, 307-317. https://doi.org/10.1016/j.rse.2014.12.019

Mika, K., Ulla, P., Karila, K., \& Juha, H. (2008). Forest Biomass Estimation Using ALOS PALSAR Images in Challenging Natural Forest Area in Finland. Proceedings of the ALOS PI 2008 Symposium, ESA Special Publication: Island of Rhodes, Greece, 3-7 November 2008.

Mitchard, E. T. A., Saatchi, S. S., Lewis, L. S., Feldpausch, T. R., Woodhouse, I. H., Sonke, 
B., Rowland, C., \& Meir, P. (2011). Measuring Biomass Changes Due to Woody Encroachment and Deforestation/Degradation in a Forest-Savanna Boundary Region of Central Africa Using Multi-Temporal L-Band Radar Backscatter. Remote Sensing of Environment, 115, 2861-2873. https://doi.org/10.1016/j.rse.2010.02.022

Morel, C. A., Saatchi, S. S., Malhi, Y., Berry, J. N., Banin, L., Burslem, D., Nilus, R., \& Ong, C. R. (2011). Estimating Aboveground Biomass in Forest and Oil Palm Plantation in Sabah, Malaysian Borneo Using ALOS PALSAR Data. Forest Ecology and Management, 262, 1786-1798. https://doi.org/10.1016/j.foreco.2011.07.008

Moskal, L. M., \& Zheng, G. (2011). Retrieving Forest Inventory Variables with Terrestrial Laser Scanning (TLS) in Urban Heterogeneous Forest. Remote Sensing, 4, 1-20.

Nguyen, T. M. D. (2015). Nghiên cứu công tác quản lý bảo tôn đa dạng sinh học tại vườn quốc gia Yok Don, tỉnh Đăk Lăk. Luận án tiến sĩ, Trường Đại học Nông Lâm TP. Hồ Chí Minh (Vietnam Language) - Research on Biodiversity Conservation Management in Yok Don National Park, Dak Lak Province. Doctoral Dissertation, Ho Chi Minh City University of Agriculture and Forestry (Translated into English by Luong).

Nguyen, T. T. (2009). Modelling Growth and Yield of Dipterocarp Forests in Central Highlands of Vietnam. Ph.D. Dissertation, München: Technische Universität München.

Peregon, A., \& Yamagata, Y. (2013). The Use of ALOS/PALSAR Backscatter to Estimate Above-Ground Forest Biomass: A Case Study in Western Siberia. Remote Sensing of Environment, 137, 139-146. https://doi.org/10.1016/j.rse.2013.06.012

Pham, T. D., Le, N. N., Ha, N. T., Nguyen, L. V., Xia, J., Yokoya, N. et al. (2020). Estimating Mangrove Above-Ground Biomass Using Extreme Gradient Boosting Decision Trees Algorithm with Fused Sentinel-2 and ALOS-2 PALSAR-2 Data in Can Gio Biosphere Reserve, Vietnam. Remote Sensing, 12, 777. https://doi.org/10.3390/rs12050777

Pham, T. D., Xia, J., Ha, N. T., Bui, D. T., Le, N. N., \& Tekeuchi, W. (2019). A Review of Remote Sensing Approaches for Monitoring Blue Carbon Ecosystems: Mangroves, Seagrasses and Salt Marshes during 2010-2018. Sensors, 19, 1933.

https://doi.org/10.3390/s19081933

Ramankutty, N., Gibbs, H. K., Achard, F., Defries, R., Foley, J. A., \& Houghton, R. A. (2007). Challenges to Estimating Carbon Emissions from Tropical Deforestation. Global Change Biology, 13, 51-66. https://doi.org/10.1111/j.1365-2486.2006.01272.x

Ranson, K. J., \& Sun, G. (1994). Mapping Biomass of a Northern Forest Using Multifrequency SAR Data. IEEE Transactions on Geoscience and Remote Sensing, 32, 388-396. https://doi.org/10.1109/36.295053

Richards, J., Sun, G. Q., \& Simonett, D. S. (1987). L-Band Radar Backscatter Modeling of Forest Stands. IEEE Transactions on Geoscience and Remote Sensing, 25, 487-498. https://doi.org/10.1109/TGRS.1987.289861

Ripple, W. J., Wang, S., Isaacson, D. L., \& Paine, D. P. (1991). A Preliminary Comparison of Landsat Thematic Mapper and SPOT-1 HRV Multispectral Data for Estimating Coniferous Forest Volume. International Journal of Remote Sensing, 12, 1971-1977. https://doi.org/10.1080/01431169108955230

Sandberg, G., Ulander, L. M., Fransson, J. E. S., Holmgren, J., \& Le Toan, T. (2011). Land P-Band Backscatter Intensity for Biomass Retrieval in Hemiboreal Forest. Remote Sensing of Environment, 115, 2874-2886. https://doi.org/10.1016/j.rse.2010.03.018

Santos, J. R., Lacruz, M. P., Araujo, L. S., \& Keil, M. (2002). Savanna and Tropical Rainforest Biomass Estimation and Spatialization Using JERS-1 Data. International Journal of Remote Sensing, 23, 1217-1229. https://doi.org/10.1080/01431160110092867

Sharifi, A., Amini, J., \& Tateishi, R. (2016). Estimation of Forest Biomass Using Multiva- 
riate Relevance Vector Regression. Photogrammetric Engineering \& Remote Sensing, 82, 41-49. https://doi.org/10.14358/PERS.83.1.41

Sheridan, R. D., Popescu, S. C., Gatziolis, D., Morgan, C. L., \& Ku, N. W. (2014). Modeling Forest Aboveground Biomass and Volume Using Airborne LiDAR Metrics and Forest Inventory and Analysis Data in the Pacific Northwest. Remote Sensing, 7, 229-255. https://doi.org/10.3390/rs70100229

Sinha, S., Jeganathan, C., Sharma, L. K., \& Nathawat, M. S. (2015). A Review of Radar Remote Sensing for Biomass Estimation. International Journal of Environmental Science and Technology, 12, 1779-1792. https://doi.org/10.1007/s13762-015-0750-0

Stone, S., \& León, Ch. M. (2011). Climate Change and the Role of Forest. A Community Manual. Arlington, VA: Conservation International.

Sun, G., Ranson, J. K., \& Kharuk, L. V. (2002). Radiometric Slope Correction for Forest Biomass Estimation from SAR Data in the Western Sayani Mountains, Siberia. Remote Sensing of Environment, 79, 279-287. https://doi.org/10.1016/S0034-4257(01)00279-6

Ulaby, F. T., Moore, R. K., \& Fung, A. K. (1981). Microwave Remote Sensing: Active and Passive (Vol. 1, 456 p). Reading, MA: Addison-Wesley.

UN-REDD Vietnam (2012). Guidelines on Destructive Measurement for Forest Biomass Estimation (35 p). UN-REDD Vietnam Programme.

Van Vo, H., Van Tran, H., \& Ngoc Pham, B. (2006). Handbook for Vietnam Forest Inventory (95 p). Ministry of Agriculture and Rural Development of Vietnam (MARD).

Vincent, M. A., \& Saatchi, S. S. (1999). Comparison of Remote Sensing Techniques for Measuring Carbon Sequestration. JPL Jet Propulsion Laboratory, California Institute of Technology.

Vu Tan, P., Viet Nguyen, X., Trieu Thinh, D. et al. (2012). Part B-6. Tree Allometric Equations in Evergreen Broadleaf, Deciduous, and Bamboo Forests in the Central Highland Region, Viet Nam (96 p). UN-REDD Vietnam Programme.

Way, A. D., \& Pearcy, W. R. (2012). Sunflecks in Trees and Forests: From Photosynthetic Physiology to Global Change Biology. Tree Physiology, 32, 1066-1081.

https://doi.org/10.1093/treephys/tps064

Wu, S. T. (1987). Potential Application of Multipolarization SAR for Pine-Plantation Biomass Estimation. IEEE Transactions on Geoscience and Remote Sensing, 25, 403-409. https://doi.org/10.1109/TGRS.1987.289811

Zhao, K., Popescu, S., \& Nelson, R. (2009). Lidar Remote Sensing of Forest Biomass: A Scale-Invariant Estimation Approach Using Airborne Lasers. Remote Sensing of Environment, 113, 182-196. https://doi.org/10.1016/j.rse.2008.09.009 